Висновки. Пропонована нами навчальна дисципліна «Етика викладача закладу вищої освіти» спрямована на формування у майбутніх педагогів норм, принципів і правил морально-етичної поведінки, тобто духовного стрижня особистості. У ході аналізу розкрито соціальну та психологічну значущість дотримання викладачем норм професійної етики. Основний акцент зроблено на тому, що моральні цінності студентів передусім формуються під впливом власного прикладу викладачів, а не під впливом того, що вони говорять. Зважаючи на це, ключову увагу приділено особистісним характеристикам викладача вищої школи, його спонуканню до самоаналізу власних учинків, визначенню типових недоліків у поведінці, пов'язаних із порушенням норм професійної моралі. Цілком логічно зміст відображає сутність, принципи, методи, психологічні механізми морально-етичного виховання, оскільки саме його покладено в основу формування морально-етичних цінностей. Досить змістовними є теми, пов'язані 3 етичними нормами педагогічного спілкування викладача 3 колегами та студентами, забезпечення взаємного контакту, попередження та розв'язання конфліктних ситуацій. Чітко визначено загальні, фахові компетентності та результати оволодіння навчальною дисципліною.

Подальші дослідження у даному напрямі плануємо присятити питанням попередження та розв'язання конфліктів у діяльності викладача закладу освіти, зокрема й булінгу.

\section{СПИСОК ВИКОРИСТАНОЇ ЛІТЕРАТУРИ}

1. Батищев Г. С. Найти и обрести себя. Bопросы философии. 1995. № 3. С. 103-109.

2. Винославська О. В., Малигіна М. П. Людські стосунки : навч. посіб. Вид. 2-е, перероб. та доповн. Київ : Центр навчальної літератури, 2006. 142 с.

3. Каплінський В. В. Загальнопедагогічна підготовка до курсового та комплексного державного екзамену (осв.-квал. рівень «бакалавр»). Вінниця : ТОВ «Нілан-ЛТД», 2015. 104 с.

4. Каплінський В. Методика викладання у вищій школі : навчальний посібник. Вінниця : ТОВ «Нiланд-ЛТД», 2015. 222 с.

5. Каплінський В. В. 100 складних ситуацій на уроках та поза уроками: шукаємо рішення : навчальний посібник для майбутніх учителів. Київ : Центр навчальної літератури, 2017. 80 с.

6. Оболонский А. В. Этика публичной сферы и реалии политической жизни. Изд. 2-е, эл. Москва : Социум, 2020. 448 c. URL: https://rucont.ru/efd/719373 (дата звернення: 10.06.2020).

7. Орлов В. Професійне становлення особистості педагога у вимірах класичної методології. Науковий вісник Інституту професійно-технічної освіти НАПН Украӥни. Серія «Професійна педагогіка». 2014. № 8. C. 103-111.

8. Юнг К. Психология бессознательного. Пере. с англ. Изд. 2-е. Москва : Когито Центр, 2010. 352 с.

Дата надходження до редакиї: 03.08.2020 p.

Наталія ЛАВРИЧЕНКО, доктор педагогічних наук, професор кафедри іноземних мов та методики викладання

Глухівського начіонального педагогічного університету імені Олександра Довженка,

м. Глухів Сумської області
УДК 37.04

DOI: 10.37026/2520-6427-2020-103-3-172-177

\title{
СОЦІАЛЬНО ОБДАРОВАНА ОСОБИСТІСТЬ: ЗДІБНОСТІ, ЯКОСТІ, РОЗВИТОК
}

У статті здійснено аналіз соціальної обдарованості в теоретичному $і$ прочесуальному (діяльнісному) аспектах. Визначено специфіку соціальноі обдарованості, зумовлену природними задатками й набутими здібностями (соціальний інтелект, емоційний інтелект, здатність до міжособистісної $i$ колективної взаємодіï) особистості.

Ключові слова: сочіальна обдарованість, соціальний інтелект, емоційний інтелект, соиіальна діяльність.
Статья посвящена анализу сочиальной одаренности в теоретическом и процессуальном (деятельностном) аспектах. Определена спещифика сочиальной одаренности, обусловленная природньми задатками и приобретенными способностями (социальный интеллект, эмоциинальный интеллект, способность кмежличностному и коллективному взаимодействию) личности.

Ключевые слова: сочиальная одаренность, сочиальный интеллект, эмоциональный интеллект, социиальная деятельность. 
The article is devoted to the analysis of social giftedness in the theoretical and procedural (activity) aspects. The specifics of social giftedness, conditioned by natural inclinations and acquired abilities (social intelligence, emotional intelligence, ability to interpersonal and group interaction) were determined. The development of social giftedness was revealed as a process covering the preparatory and productive phases. The preparatory phase is made up by developing a gifted personality from early childhood to adulthood and it is subject to both spontaneous and purposeful pedagogical influences. Particular attention was paid to children's play as an important factor in developing children's social abilities and at the same time the way they are manifested. The productive phase is considered to be the one marked by the personal and professional maturity of socially gifted individuals as public figures. It was substantiated that leadership, management, serving are the areas of activity in which socially gifted individuals most often and most effectively demonstrate their abilities.

The aim of the article is to reveal the essence of social giftedness as a concept, to determine the characteristics and abilities of gifted individuals in the activity context.

As a result, the essence of social giftedness was explained on the basis of its defining feature - the subject-subject way of its realization. This, in its turn, determines the specific talents and abilities of socially gifted individuals, including such ones as self-actualization, assertiveness, constructive approach to solving problems, optimism, realistic disposition, adequate self-esteem, independence, flexibility, social perception, social solidarity, and responsibility.

It was concluded that talented, charismatic leaders and managers are able to significantly improve the quality of life of the community but only on condition they adhere to moral and ethical norms and rules, subtly feel and profoundly understand the social demands and development trends. On the other hand, the community in which socially gifted individuals are formed is a prerequisite and the main driver of developing people with the charisma of leadership, management, and serving.

Key words: social giftedness, social intelligence, emotional intelligence, social activity.

Постановка проблеми. Відповідно до найзагальнішої класифікації обдарованих людей можна поділити на дві категорії: твориів і діячів. Представники першої категорії проявляють і застосовують свій талант переважно у процесі взаємодії зі світом живої природи і матеріальних об'єктів, а другої - у взаємодії зі світом людей. Однак варто пам'ятати, що цей поділ $є$ доволі умовним, позаяк у реальному житті досягнення твориів, як-от визначні винаходи, наукові відкриття, художні шедеври тощо, стають можливими завдяки безпосередній або опосередкованій підтримці іншої категорії - діячів, які навчають, консультують, надихають, спрямовують, спонукають, організовують, оптимізують, прискорюють творчий процес. Проте роль соціально обдарованих діячів не завжди можна виміряти й належним чином оцінити, а як наслідок - їхній реальний внесок часто залишається «в тіні» слави творців. 3 огляду на це, теоретичні й прикладні дослідження в галузі соціальної обдарованості набувають особливого значення як такі, що дають змогу: 1) осмислювати й розуміти соціальну обдарованість як явище; 2) усвідомлювати роль соціально обдарованих діячів у суспільному поступі;
3) розробляти стратегії підтримки й оптимального використання потенціалу соціально обдарованих людей.

Аналіз наукових досліджень і публікацій. Проблеми, пов'язані із соціальною обдарованістю, перебувають у зоні уваги багатьох учених, зокрема й тих, які цікавляться соціальними відносинами, психологією соціальної поведінки, соціальним розвитком людини, соціалізацією як педагогічним процесом. Американський психолог і педагог Едвард Торндайк був одним із перших, хто долучився до розроблення проблеми соціальної обдарованості. Він зосередився на «соціальному інтелекті» та потлумачив це поняття як «здатність розуміти людей, управляти жінками й чоловіками, хлопчиками й дівчатками, бути розсудливими в людських стосунках» [17, с. 228].

Говард Гарднер наблизився до теми соціальної обдарованості, працюючи над авторською теорією множинного інтелекту. Учений зробив висновок, що люди із добре розвиненим міжособистісним інтелектом здатні помічати риси характеру, особливості поведінки, настрої інших людей, визначати їхній темперамент, розпізнавати наміри й бажання, навіть приховані, й, зважаючи на це, вибудовувати міжособистісні стосунки [2, с. 293; 11].

Значний внесок у розвиток теорії соціальної обдарованості зробили вчені-психологи, які досліджують емоційний інтелект. Одна із відомих моделей емоційного інтелекту належить Деніелу Гоулману. Вона складається із п'яти структурних компонентів: 1) самоусвідомлення; 2) управління власними емоціями; 3) мотивування емоцій інших людей; 4) емпатія; 5) підтримання зв'язків [12, с. 20-26].

Рувен Бар-Он шляхом інтеграції теоретичних здобутків у галузі соціального та емоційного інтелекту створив модель емоційно-соціального інтелекту, яка відкриває нові грані та нову якість соціальної обдарованості. На думку автора, синтез емоційних і соціальних здібностей створює додаткові можливості для соціального розвитку особистості, що позначається на здатності людини розпізнавати, усвідомлювати й виражати емоції, почуття; розуміти, що відчувають інші люди й підтримувати з ними стосунки; управляти власними емоціями та тримати їх під контролем; бути менеджерами змін, адаптуватися до них, розв'язувати проблеми персонального і міжперсонального характеру; генерувати позитивні емоції й мотивувати себе $[16$, с. $13-25]$.

Для розвитку теорії соціальної обдарованості важливе значення має теоретичний доробок Роберта Стернберга щодо ролі практичного інтелекту в розв'язуванні повсякденних проблем, управлінні собою та іншими людьми, ситуаціями. За висновками вченого, практичний інтелект дає змогу набувати соціального досвіду і напрацьовувати систему цінностей, що веде до появи мудрості як здатності узгоджувати індивідуальний і колективний інтерес; зважаючи на особисте й суспільне благо, визначати стратегію діяльності, враховувати зовнішні умови (контекст), а в разі потреби впроваджувати зміни (адаптаційні, селекційні, трансформаційні) в соціальному середовищі [13, с. 327-342].

Мета статті - розкрити сутність соціальної обдарованості як поняття; визначити характерні риси й здібності обдарованих індивідів у діяльнісному контексті. 
Виклад основного матеріалу. Попри те, що розглянуті теорії відрізняються авторським розумінням проблеми соціальних здібностей, їх поєднує наявність таких змістових блоків, як сочіальний інтелект, емоиійний інтелект, соиіальна дія (діяльність), що дає підстави розглянути ці теоретичні конструкти як засадничі для розуміння соціальної обдарованості як поняття.

В. Кантор та Б. Кільстрем тлумачать соціальний інтелект як здатність формувати стратегії досягнення цілей, короткострокових і довгострокових; спілкуватися з людьми, доречно розподіляти ресурси, бути стійкими стосовно відкладеної винагороди [6, с. 272].

Не вдаючись до аналізу інших визначень соціального інтелекту, зазначимо, що в контексті дослідження сочіальної обдарованості сочіальний інтелект слід розглядати передусім як успішний інтелект, тобто такий, що дає змогу ефективно й продуктивно розв'язувати складні соціальні проблеми. Обдаровані особистості 3 розвиненим соціальним інтелектом можуть бути успішними в одній і більше видах діяльності, наприклад:

- генерувати креативні й цінні ідеї, показувати їх значущість для соціального оточення;

- аналізувати й визначати соціальні умови, сприятливі для реалізації інноваційних ідей, проєктів;

- знаходити потрібну інформацію й ефективно оперувати нею у процесі вирішення суперечливих, конфліктних ситуацій;

- обирати ефективні стратегії діяльності, добирати потрібних людей для втілення їх у життя;

- розуміти соціальні процеси, закономірності й тенденції їхнього розвитку;

- прогнозувати поведінку людей і перспективи міжособистісних, групових відносин;

- дотримуватися здорового прагматизму, не переступаючи межі загальнолюдських цінностей і конвенціональних правил.

Принагідно зауважимо, що наявність соціального інтелекту не завжди свідчить про автоматичну готовність, бажання і можливість ним скористатися. Тоді б, напевно, рідше траплялося таке явище, як помилка атрибуиіiі. Тобто, йдеться про випадки, коли про людину складають думку, зважаючи передусім на iii зовнішній вигляд, особистісні диспозиції, але при цьому забуваючи про вплив життєвих обставин і ситуацій. Звичайно, найлегше все списати на внутрішні установки людини (диспозиції), аніж з'ясовувати чи аналізувати ситуації, адже для цього необхідно докласти чимало як інтелектуальних, так і психічних зусиль [4, с. 113].

Соціально обдаровані особистості можуть досягати високої точності передбачень поведінки інших людей, спостерігаючи їх у досить обмеженій кількості ситуацій, здатні долати суб'єктивні погляди за допомогою аналітичного мислення, зіставлення фактів та інформації. I в цьому - їхня перевага порівняно 3 тими, хто мислить упереджено (помилка атрибуції), штампами (інтерпретативні схеми) або ж взагалі не має власної думки (індеферентність, дезорієнтація).

Таким чином, соціальний інтелект загалом - це знання соціального світу. Соціально обдарована особистість спроможна скористатися цим знанням для покращення якості життя, як власного, так і інших людей. Соціальний інтелект набуває істотного підкріплення, коли поєднується 3 емоційним і практичним інтелектом (чутливістю й дієвістю). Унаслідок такого синтезу формується соціальна компетентність як здатність ефективно застосовувати соціальні знання релевантно контексту [15, с. 28-39], посилюється соціальна перцепція - спроможність цілісно сприймати соціальні об'єкти - людей, соціальні групи [1].

Емоційний інтелект покликаний виконувати важливу функцію посередника між раціональними рішеннями і конкретними діями, а в деяких випадках ще й запобіжника домінування «сухого» раціо над учинками. Поняття емоційного інтелекту додає глибини усвідомленню того, що загалом означає розум i розумна соціальна поведінка. Особливість емоційного інтелекту полягає в тому, що він може функціонувати в режимі оперативного, реактивного, інтуїтивного знання й осягнення соціальної реальності [18, с. 19].

Обдарованим людям із розвиненим соціальним та емоційним інтелектом властиві такі якості:

- стійкість до стресу (ефективне і конструктивне управління емоціями);

- самоактуалізація (цілеспрямованість, прагнення реалізувати власний потенціал);

- асертивність (конструктивне й ефективне утвердження та реалізація власних намірів і бажань);

- розв'язання проблем (конструктивний підхід до персональних і міжперсональних проблем);

- оптимізм (позитивний настрій, сприйняття життя із позицій добра і світла);

- реалістична диспозиція (об'єктивне сприйняття й оцінка почуттів і думок інших людей);

- адекватна самооцінка (об'єктивне сприйняття й оцінка власних здібностей і можливостей, прийняття себе);

- незалежність (упевненість у собі, вміння зберігати собі тотожність, свободу думки й почуттів);

- гнучкість (уміння адаптуватися до нових умов, планувати дії з урахуванням настроїв і намірів інших людей, змін у соціумі);

- соціальна солідарність і відповідальність (ідентифікація 3 певною соціальною групою, дотримання корпоративних інтересів, колективна співпраця задля досягнення погодженої мети).

Зауважимо, що поза соціальною активністю про соціальний інтелект та емоційний інтелект можна говорити передусім як про потенціал соціально обдарованої особистості, який може стати реальною перевагою лише в процесі соціальної діяльності. Найбільш сприятливими для цього є такі види діяльності, як лідерство, менеджмент та служіння.

Лідер, за Г. Гарднером, це - людина, яка здатна змусити інших людей робити навіть те, що їм не дуже подобається. При цьому вчений розрізняє два типи лідерства: пряме (безпосереднє керівництво до дії, спонукання) і непряме (заохочення власним прикладом), які можуть бути однаково результативними [10].

Ф. Ганє переконаний, що обдарований від природи лідер наділений здібностями, необхідними для успішного виконання своєї ролі. Природжені лідери успішно взаємодіють 3 іншими людьми, чітко й зрозуміло висловлюють свої погляди й прагнення, добре знають себе і розуміють інших. До речі, в авторській моделі обдарованості Ганє відніс лідерські здібності до розряду «соціально-афективних» [9, с. 60-74].

Від людей із лідерськими здібностями соціум найчастіше очікує конструктивних, інноваційних змін як внеску в загальний добробут. А для того, щоб відповідати цим сподіванням, лідерові, крім соціальної компетентності, необхідні також особистісні якості, як-от незалежність суджень, переконаність 
у правильності обраної стратегї̈, стійкість, наполегливість у досягнення мети, рішучість, впливовість, сила волі, віра в успіх. Обдарований лідер може досягати позитивних змін, застосовуючи різні стратегії, наприклад: переносити успішні моделі діяльності на нову справу (галузь), застосовувати успішні моделі діяльності в нових, змінених умовах; «розвернути» процес діяльності у зовсім іншому (іноді несподіваному) напрямі, вдаватися до реконструкції процесів шляхом повернення до вихідної точки й зміни вектора руху; корегувати, уточнювати погляди та ідеї як керівництво до дії, повністю змінювати парадигму діяльності в сукупності цілей, методів, прийомів, засобів, ресурсів, ціннісних критеріїв.

На думку Р. Стернберга, лідер має поєднувати в собі розум, креативність, досвід і демонструвати мудрість як результат синтезу цих якостей. Без такої повноти й цілісності його лідерські здатності можуть бути розтрачені марно. Комусь не вистачить креативності генерувати «свіжі» й конструктивні ідеї, комусьаналітичних інтелектуальних здібностей для того, щоб зрозуміти цінність нових ідей, а комусь забракне практичного інтелекту, щоб переконати інших у цінності ідей і втілити їх у життя, або ж мудрості мотивувати себе й інших до реалізації цих інноваційних ідей [14, с. 37-44].

Харизматичні лідери часто наділені неабияким зарядом енергії, специфічним магнетизмом, що дає їм змогу вести за собою велику кількість людей. Однак, пропорційно до сили впливу, на лідера покладається відповідальність за кінцевий результат, за чистоту помислів, за дотримання моральних норм і загальнолюдських цінностей, за долю людей, яких він веде за собою. При цьому слід зауважити, що відповідальність за результат стосується спільноти не менше ніж лідера, адже саме суспільство формує запит на постать лідера і має для цього чимало механізмів, серед яких: делегування прав і обов'язків, конвенціональне погодження правил і норм, колективна солідарність i спонукання, утвердження ціннісних пріоритетів, процесуальний моніторинг діяльності. Зважаючи на викладене вище, доречно навести цитату С. Рубінштейна: «Участь у суспільному житті формує суспільні почуття... Почуття людини опосередковані й зумовлені реальними суспільними відносинами, в яких задіяна людина, правами й звичаями суспільного середовища і його ідеологією» [7, с. 557].

Роль лідера тісно пов'язана з управлінською діяльністю. Так, з одного боку, важко уявити лідера, який не управляє людьми й процесами, а $з$ іншого - не може бути успішним менеджер, який не є лідером, або якого таким не визнають. Утім у зв'язку з цим варто нагадати такі досить поширені міфи про менеджерів: 1) талановитих менеджерів не буває або ж це надзвичайна рідкість; 2) управлінська діяльність - це рутина, яка не вимагає особливих здібностей і талантів.

Практика не тільки спростовує ці міфи, а також доводить, що ролі лідера й менеджера є суміжними, проте не тотожними. Скажімо, якщо обдарований лідер зазвичай $є$ стратегом, конструктором, каталізатором позитивних змін у спільноті, то гарний менеджер - це геній продуктивності, рентабельності, доданої вартості. Отже, соціальна ефективність менеджера залежить передусім від таких здібностей і якостей, як: раціональність, інтуїція, здатність до ризику, передбачливість, кмітливість, підприємливість, винахідливість, чесність, відповідальність, дисципліна, фахова компетентність, креативність, знання людей та вміння об'єктивно оцінювати їхні здібності.

Одне з головних завдань успішного менеджера підібрати персонал із необхідним рівнем кваліфікації та людськими якостями. «Ростити» фахівців, підвищувати їхній рівень - це нерентабельне заняття для менеджера, тому він імовірніше передоручить його досвідченим тренерам, наставникам, коучам. Власні здібності менеджер насамперед спрямує на формування дієздатної команди, дбатиме про оптимальний розподіл обов'язків задля досягнення максимально можливого коефіцієнту корисної дії.

Обдарований менеджер здатний миттєво (емпатійно) зрозуміти, якими здібностями володіє кожен член команди, а якщо забракне інтуїтивного чуття - збере додаткову інформацію, вивчить ситуацію i зрештою прийме правильне рішення. Він високо цінує кожну досконало зроблену роботу, однак найбільшу підтримку надає тим працівникам, які якнайкраще забезпечують продуктивність, конкурентоздатність команди (фірми, організації, підприємства).

Талановитий менеджер - це не стільки корпоративний гравець, скільки професіонал, індивідуаліст iз неповторним стилем керівництва. По суті, він виконує ту ж саму роботу, що і його колеги, тобто критикує, раціоналізує, мобілізує, оптимізує виробничий процес, «диригує» виробничі відносини, однак енергетичне поле, яке при цьому утворюється, неможливо механічно перенести на іншу реальність, скопіювати. По-іншому, можна сповідувати фордистський стиль управляння, але, на жаль, неможливо перетворитися на Генрі Форда.

Ще одним видом діяльності (поряд із лідерством і менеджментом) є служніння, в якому соціально обдаровані люди можуть проявити й часто проявляють свої надзвичайні здібності. Соціальні ролі, пов'язані зі служінням, зазвичай обирають за покликом душі, а вже потім - за професійним покликанням. Тобто, соціально обдаровані люди зазвичай вбачають свою місію не тільки і не стільки із точки зору протоколу, скільки важливої персональної місії. Наприклад, для вчителів - це служіння дітям, їхньому добробуту й усебічному розвитку; для медиків та психологів - здоров'ю й здоровому способу життя; для священників - духовним запитам і потребам людини; для військових - охороні мирного життя громадян. Фахові здібності й компетентності тих, хто служить людям, за необхідності доповнюються морально-етичними приписами, що слугують своєрідним кодексом честі, фаховості й вірності обраній справі: у медицині - це клятва Гіппократа; на військовій службі - Присяга; у релігійному сані - Заповіді Божі; у педагогіці - педагогічне кредо як система принципів, правил і цінностей.

Незалежно від соціального статусу й ролі, соціально обдаровані люди з харизмою служіння $є$ завжди більшими, масштабнішими за обрану професію. Це проявляється в духовному розвиткові, широті інтересів, діапазоні знань і вмінь, особистісному внеску, який вони лишають по собі. Так, прикладами високого служіння людям і людяності є Мати Тереза, Нельсон Мандела, Махатма Ганді, Януш Корчак, Далай-лама XIV.

Вочевидь, що розглянуті види, напрями діяльності, в яких найчастіше знаходять себе соціально обдаровані люди, є доволі складними, багатоаспектними й такими, що вимагають не лише фахової компетентності, а й високого рівня особистісної зрілості, мудрості. 
У зв’язку з цим постає запитання: «Соціальна обдарованість - це прерогатива дорослих людей?». Можна сказати, що так, якщо ототожнювати соціальну обдарованість із результатом. Однак результат - це фінальне досягнення в соціальній діяльності й, що важливо, включно із підготовкою, адже в такій надскладній діяльності, як робота з людьми, цільова підготовка набуває вирішального значення і фактично рівноцінна шансу. Навіть дуже обдаровану від природи людину неможливо навчити бути соціально прийнятною, ефективною, компетентною ані за місяць, ані за рік і навіть більше, потрібен тривалий процес відповідного соціально-педагогічного супроводу, починаючи з раннього дитинства. Учені дослідили, що в період між 12-ма і 18-ма місяцями свого життя малюки докладають чималих зусиль для того, щоб розібратися із соціальними очікуваннями, і тим, що відбувається, коли вони досліджують соціальний світ і перевіряють «гіпотези» щодо його устрою. Під кінець цього періоду вони вже впізнають себе на фотографіях та в дзеркалі й готові до більш цілеспрямованої соціалізації. У віці 18-30 місяців діти набувають досить важливих знань про себе як частину соціального світу (поняття статі, що таке добре, а що - погано, що у них виходить добре, а що - не дуже тощо). Прикладом того, що діти починають краще усвідомлювати власні почуття, $є$ те, як гостро вони реагують на фрустрацію й образи. Так звані свідомі емоції - гордість, вина, сором, ніяковість - можуть бути поміченими навіть в однорічних малят. Ці емоції залежать як від інтелектуального розуміння соціальних норм на досить високому рівні, так і від «Я»-відчуття. Тобто, малюк уже повинен уміти визначити, наскільки його поведінка відповідає нормам, встановленим культурою, і до якого результату вона призведе - до успіху чи невдачі. Із моменту, коли дітям виповнюється 2,5-3 роки, розпочинається процес інтерналізації суспільних норм і перехід на орієнтацію на них у власній поведінці, незалежно від того, є поруч дорослі чи немає [3, с. 334].

Дітей, в яких соціальні навички й здатності розвинені краще, ніж у ровесників, можна помітити у будь-якому віці. Зазвичай такі діти користуються популярністю в дитячих групах. Вони швидше за інших установлюють контакти, здатні ненав'язливо включатися в гру, дружелюбні, роблять доречні пропозиції й продумані зауваження у процесі взаємодії, чутливі до змін у настроях інших дітей, енергійні й винахідливі. Дорослі наставники найчастіше дають соціально здібним дітям такі характеристики:

- чутливі до потреб і дій інших;

- не нав'язують свою волю іншим дітям;

- погоджуються гратися поруч з іншими дітьми;

- уміють підтримувати дружні стосунки;

- приходять на допомогу, коли це потрібно;

- уміють підтримати розмову;

- діляться цікавою інформацією;

- відгукуються на пропозиції інших дітей;

- здатні вирішувати конфлікти;

- у конфліктних ситуаціях не схильні до проявів агресії та застосування грубої фізичної сили [3, с. 427].

Соціально обдаровані діти зазвичай посідають найсприятливіші позиції в дитячому колективі. Вчителі та вихователі відзначають їхню здатність бути гарними партнерами у грі: проявляти організаторські здібності, погоджувати розподіл ролей, уводити в гру щось нове, збагачувати іiї тощо [5, с. 187].
Дитячу гру загалом можна розглядати як унікальний тестер соціальних здібностей дітей. Так, учені встановили, що існує корелятивне співвідношення між когнітивною складністю ігор і соціальними здібностям дітей у стосунках із однолітками. Діти будь-якого віку, які надають перевагу складнішим іграм, були оцінені як більш дружелюбні, менш агресивні й відчужені, більш схильні до соціально орієнтованої поведінки. На підставі проведених досліджень зроблено висновок, що складність гри дитини, особливо імітаційно-рольової, слугує надійним показником іiї соціальної компетентності на майбутнє. Наприклад, імітаційна гра у дошкільному віці дає можливість оволодіти ефективною комунікацією 3 однолітками, знаходити компроміс в обговоренні ролей, уникати неприємних переживань, краще зрозуміти емоції, як власні, так і чужі, отримувати й надавати підтримку учасникам гри [8, с. $882-883] .3$ огляду на це, імітаційно-рольові ігри є не лише індикатором, а також своєрідним тренінгом соціальної взаємодії, адже допомагають розвивати комунікативні навички, лідерські здібності, навчають співпрацювати, управляти процесом колективної взаємодії, формувати текст і контекст міжособистісних інтеракцій.

Висновки. Отже, підсумовуючи, зауважимо, що соціальна обдарованість є багатоаспектим явищем і сферою діяльності, в якій людина може бути одночасно як суб'єктом, так і об'єктом. Із цим пов'язана специфіка соціальної обдарованості, адже в усіх інших галузях обдарованості людина є суб'єктом взаємодії із живою природою і матеріальними речами.

В основу соціальної обдарованості як процесу покладено соціальний інтелект, емоційний інтелект і соціальну діяльність. Найкраще соціально обдаровані особистості можуть реалізувати себе в таких видах (напрямах) діяльності, як лідерство, менеджмент, служіння.

Соціальну обдарованість як явище важливо досліджувати й осмислювати як із точки зору результату, так і процесу. Складніша й відповідальніша діяльність вимагає тривалішої та більш ретельної підготовки навіть тоді, коли дитина має для цього неабиякий природжений потенціал. У зв'язку з цим набуває особливої актуальності й значення рання діагностика соціально обдарованих дітей, їхній психолого-педагогічний супровід із метою якомога повнішого розкриття природних здібностей і набуття необхідного соціального досвіду й компетентності.

\section{СПИСОК ВИКОРИСТАНОЇ ЛІТЕРАТУРИ}

1 Бодалев А. А. Восприятие и понимание человека человеком. Москва : Изд-во Моск. ун-та, 1982. $200 \mathrm{c}$.

2. Гарднер Г. Структура разума: теория множественного интеллекта / пер. с англ. Москва : ООО «И. Д. Вильямс», 2007. 512 с.

3. Крайг Г. Психология развития. Изд. 7-е, междунар. Санкт-Петербург, 2000. 987 с.

4. Майерс Д. Социальная психология / пер. с англ. Санкт-Петербург : Питер, 1996. 682 с.

5. Реан А. А., Коломинский Я. Л. Социальная педагогическая психология. Санкт-Петербург : Издательство «Питер», 2000. - 416 с.

6. Росс Л., Нисбетт Р. Человек и ситуация. Уроки социальной психологии / пер. с англ. В. В. Румынского ; под. ред. Е. Н. Емельянова, В. С. Магуна. Москва : Аспект - Пресс, 2000. 429 с. 
7. Рубинштейн С. Л. Основы общей психологии. Санкт-Петербург : Издательство «Питер», 2000. - 712 с.

8. Шэффер Д. Дети и подростки. Психология развития. Изд. 6-е. Санкт-Петербург : Питер, 2003. 973 с.

9. Gagne F. Transforming gifts into talents: the

DMGT as $\mathrm{f}$ developmental theory. Handbook of gifted education ( $3^{\text {rd }}$ ed.). N. Colangelo, G. A. Davis. Boston: Allyn and Bacon, 2003.

10. Gardner H. Leading Minds. New York : Basic Books, 1995. 480 p.

11. Gardner H. Frames of Mind: The theory of multiple intelligences. New York : Basic Books, 1983. 464 p.

12. Goleman D. The emotional intelligence of leaders. Leader to Leader, 1998 (10). 1998. P. 20-26.

13. Sternberg R. J. The WICS model of giftedness. In R. J. Sternberg, J. E. Davidson (eds). Conceptions of giftedness. ( $2^{\text {nd }}$ ed.). New York : Cambridge University Press, 2005. P. 327-342.
14. Sternberg R. J. WICS: A model of giftedness in leadership. Roeper Review, 28. 2005. P. 37-44.

15. Topping K., Bremner W., Holmes E. A. Social competence: the social construction of the concept. In R. Bar-On, J. D. A. Parker (Eds.). The handbook of emotional intelligence: theory, development, assessment, and application at home, school, and in the workplace. San Francisco : Jossey-Bass, 2000. P. 28-39.

16. The Bar-On model of emotional-social intelligence (TSI). Psicothema, 18 (surpl.), 2006. P. 13-25.

17. Thorndike E. L. Intelligence and its uses. APA PsycNet, 1920. 140 p.

18. Van Rooyen J. Bar-On Emotional Quotient Inventory: Training Manual. Johannesburg: Jopie van Rooyen and Partners, 2002.

Дата надходження до редакиї: 22.05.2020 p. 